\title{
THE IMPROVEMENT OF HIGH EDUCATION QUALITY IN INDONESIA THROUGH THE CHARACTER EDUCATION
}

\author{
Ieke Sartika Iriany ${ }^{1}$, Rostiena Pasciana ${ }^{2}$
}

\begin{abstract}
Nowadays, moral education or character education; has become a relevant way to resolve moral crisis happens in Indonesia. When we said about moral crisis, it all refers to corruption, fornication, children and teen abuse, peer to peer violence, juvenile delinquency, the habit of cheating in exam, drugs abuse, pornography, and anarchy. All of it has become social problems that we still do not have the answer on how to resolve. Thus, based on the matter, character education obviously becomes an important thing to be implemented. Objective description that factually happen to the Indonesian nowadays, has show us that The Indonesian almost lost its true self (or identity). Many incidents happened in a last years, had threatened the nation existence. The spread of social conflict and terror had destroyed the social capital, which is important for the community moral integration. In other side, corruption, collusion and nepotism have turned this nation to become a low trust society. Based on the objective description above, I thought we need to improve the quality of higher educations, particularly through the character education; thus, they could result a diplomas with strong Indonesian identity. Nation Identity will be appears in the nation's character as an implementation of the highest value of the nation. For the Indonesian, the highest values of the nation clearly written in the national principle, which is Pancasila. Pancasila itself, is the establishment of religious, humanity, nationalism, sovereignty, and sociality concepts. Revitalization of Indonesian identity mean, re-build and strengthen Indonesian identity to every citizens. In other words, an effort to build a person with strong Pancasila sense whom has moral and responsible. Higher education level, in this case, has responsibility to shape and strengthening the national identity, which nowadays seems to be weakened.
\end{abstract}

Keywords: Higher education quality, and character education

\section{INTRODUCTION}

"National education functioned to develop and shape the character and nation civilization as an effort to educate the nation; and aimed to develop the potency of the students. Thus, they could rise to be a faithful individual to thee God, have a strong moral, healthy, knowledgeable, skillful, creative, independent and being a democratic and responsible citizen" (Article 3 of Republic of Indonesia Regulation, No:20, 2003 about National Education System). It is summarized the function and the aim of national education that have to used to develop Indonesian education.

The aim of national education is a set of ideas about how Indonesian quality must be developed by every education institution level, including High Education Level. Because it is become a basic to develop cultural education and character. Although in this case, we need a common understanding related to the meaning of nation character education and character, which have strong relation with Indonesian identity.

If we look again to the the Regulation of National Education System, education could be describe as culture internalisation process to each person and community, and turn them into 
civilized community. Education is not merely as knowledge transfer, but also as enculturization and socialization. A person must obtain an education that contain basic humanity dimensions. Humanity Dimension are :

(1) Afective, which reflected in faithfulness to Thee God, morality, good deeds; including, good personality and aesthetic competence.

(2) Cognitive, which reflected in mind and intelectual capacity to dig and develop the knowledge and technology; and

(3) Psychomotoric, reflected in the ability to develop technical skill, practical dan kinestetic competence.

Nowadays, moral or character education has become a relevant way to resolve moral crisis happens in Indonesia. When we said about moral crisis, it all refers to corruption, fornication, children and teen abuse, peer to peer violence, juvenile delinquency, the habit of cheating in exam, drugs abuse, pornography, and anarchy. All of it has become social problems that we still do not have the answer on how to resolve all of it. Thus, character education obviously becomes an important thing to be implemented.

In a past years, corruption has become one of trending topic in society that appear in both local mass media and national. Many experts have share their opinion about it. Basicaly, there are always the pro side and the contra one. Although, they're agree that corruption is something that could harm and damage the country from inside. It is called as "social parasyte" that easily damage goverment structure, and could be an obstacle for the country's development in general. On this matter, High Education have a great responsibility to build and shaping the character; and re-strengthen national identity that seems to be weaken.

\section{Research Problems}

Based in the description above, the problems will be discussed in this paper are :

1. How weak the Indonesian character nowadays?

2. What is Character Education?

3. What is Indonesian Identity?

4. How to revitalized Indonesian identity to increase the quality of High Education in Indonesia?

\section{Theories Background}

Character is a set of human behaviour values that relates to Thee God, self, other persons, environment and nationality; which established in mind, attitude, feeling, words, and behaviour based on religious norms, positive law, ethics, culture and customs.

According to Lickona : 2004, character relates to moral knowing, moral feeling and moral behaviour. Based on the three components, we can say that the positive character supported by knowledge about goodness, willing to do a good thing, and the action to do a good thing. The picture below shows the relation of the three. 


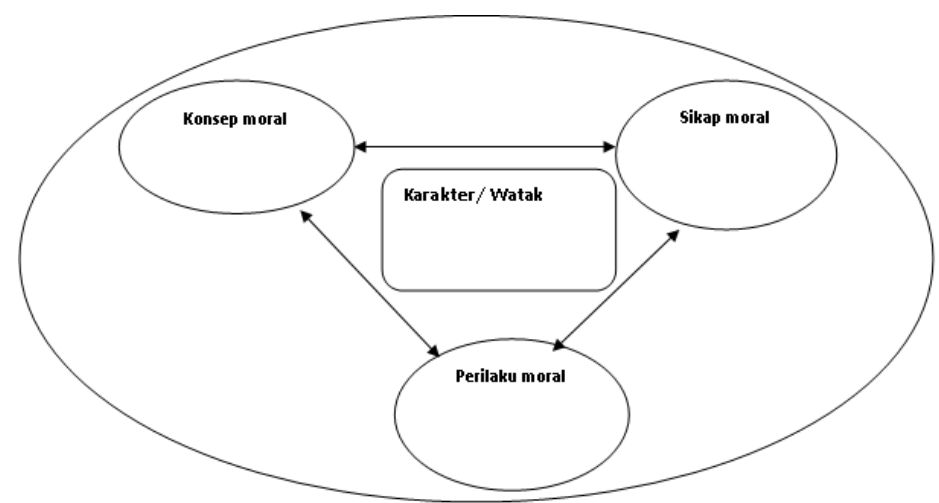

Picture 1 : Relation between moral components to build good character according to Lickona: 2004.

Below are character education description according to some experts :

a. Lickona (2004) stated that character education is an intended efort to help someone to understand, internalized and implementing the core of ethic values.

b. Suyanto (2009) describe the character as a way of thinking and behaving that become a mark of each individual to live and cooperate within a family, community, nation and country as an entity.

c. Accoding to Kertajaya, Character is an individual mark. It is original and rooted to the personality of individual or a thing; and it is a "machine" that trigger how someone must take an act, behave, communicate and respond (Kertajaya, 2010).

d. Character according to psychology dictionary is a personality sen from ethic or moral point of view. Such as honesty, and usually it is related with som constant traits (Dali Gulo, 1982: p.29)

In a character education, there are developd values through culture education and character. In other side, national character is identified through the core sources. And the core sources are Religion, Pancasila, culture and national education aims.

Indonesian is a religous people, thus their religious values automaticaly able to used to form the national character. In other side, Pancasila used as a source, since it is become the ground to build the nation and country. And, because Indonesia is formed from various ethnicities and culture, then it is also become important to invoves cultural value to create national character according to each ethnic domicile. In the education context, sourcing from religion, Pancasila and culture; thechnicaly we can formulate it through the national education aim.

National Education aim is a way to create how Indonesian quality want to be built. So, the truth is, the most technical/operational source of national character value is the National Education Aim itself. Because every education held in Indonesia can not be contradictive with the national education aim that based on Regulation No. 20, 2003 about National Education System.

Identity is a quality that could determine an individual or an entity to be acknowledge as a personal that different with another individual or entity. Quality that described an identity must be unique, special, reflecting the individual or entity. Identity is an individual refelction or an entity that personalized in an individual or entity; it is always look consistant reflecting behavior and attitude, when and individu try to resolve a problem.

There are some experts whom trying to separate the meaning of self identity and Identity. Self Identity more describe about physical appearance that manifested in a person's attitude and behavior; such as kindliness, grumpy, introvert. Extrovert, optimistic, pessimistic and so 
on. While identity is a quality that depict a person or an entity's integrity, as a God gift; which reflect individual or entity's dignity.

Identity contains the basic values that give a pattern to its supporter. A nation's identity that supports individual-liberalism will be different with them whom supports collectivism and, or socialism.

National identity will be appears in a nation's character, since it is an establishment of national supreme norms. For Indonesian, the supreme norms could be found in the National Principle, Pancasila. It is an establishment of religion, humanity, nationalism, sovereignty and socialism. Building Indonesian identity mean building an identity for every person in Indonesia; in other side, building Manusia Pancasila (Pancasila based citizen).

\section{METHODOLOGY}

This study derived from writer understanding using non research approach; in this case, writing methodology used is literatures study through theories and concept analyzing; added by documents described with verbal method.

\section{RESULT AND DISCUSSION \\ Description Of The Nation Character Weakness}

As we realize, corruption is almost impossible to eradicate, since the trial will be hard to serve the exact prove in the court. In other side, some of the case will be hard to detected using the existing law. Although we know that corruption is a latent threat for the government and society, and must be anticipated. Below is the table about corruptor based on their work function.

\section{Table 1}

Corruptor according to the Job Function

Year 2004-2014 (per 30 November 2014)

\begin{tabular}{|c|c|c|c|c|c|c|c|c|c|c|c|c|}
\hline Function & $\begin{array}{c}200 \\
4\end{array}$ & $\begin{array}{c}200 \\
5\end{array}$ & $\begin{array}{c}200 \\
6\end{array}$ & $\begin{array}{c}200 \\
7\end{array}$ & $\begin{array}{c}200 \\
8\end{array}$ & $\begin{array}{c}200 \\
9\end{array}$ & $\begin{array}{c}201 \\
0\end{array}$ & $\begin{array}{c}201 \\
1\end{array}$ & $\begin{array}{c}201 \\
2\end{array}$ & $\begin{array}{c}201 \\
3\end{array}$ & $\begin{array}{c}201 \\
4\end{array}$ & $\begin{array}{c}\text { Jumla } \\
\mathrm{h}\end{array}$ \\
\hline $\begin{array}{l}\text { Member of } \\
\text { DPR dan } \\
\text { DPRD }\end{array}$ & 0 & 0 & 0 & 2 & 7 & 8 & 27 & 5 & 16 & 8 & 3 & 76 \\
\hline $\begin{array}{l}\text { Head of } \\
\text { institution/ } \\
\text { ministry }\end{array}$ & 0 & 1 & 1 & 0 & 1 & 1 & 2 & 0 & 1 & 4 & 9 & 20 \\
\hline Ambassador & 0 & 0 & 0 & 2 & 1 & 0 & 1 & 0 & 0 & 0 & 0 & 4 \\
\hline $\begin{array}{l}\text { Commissione } \\
r\end{array}$ & 0 & 3 & 2 & 1 & 1 & 0 & 0 & 0 & 0 & 0 & 0 & 7 \\
\hline Governor & 1 & 0 & 2 & 0 & 2 & 2 & 1 & 0 & 0 & 2 & 2 & 12 \\
\hline $\begin{array}{l}\text { Mayor and } \\
\text { Deputy }\end{array}$ & 0 & 0 & 3 & 7 & 5 & 5 & 4 & 4 & 4 & 3 & 9 & 42 \\
\hline $\begin{array}{l}\text { Echelon I / II } \\
\text { / III }\end{array}$ & 2 & 9 & 15 & 10 & 22 & 14 & 12 & 15 & 8 & 7 & 2 & 116 \\
\hline Judge & 0 & 0 & 0 & 0 & 0 & 0 & 1 & 2 & 2 & 3 & 2 & 10 \\
\hline $\begin{array}{l}\text { Private } \\
\text { company }\end{array}$ & 1 & 4 & 5 & 3 & 12 & 11 & 8 & 10 & 16 & 24 & 13 & 107 \\
\hline
\end{tabular}




\begin{tabular}{lcccccccccccc}
\hline Function & $\mathbf{2 0 0}$ & $\mathbf{2 0 0}$ & $\mathbf{2 0 0}$ & $\mathbf{2 0 0}$ & $\mathbf{2 0 0}$ & $\mathbf{2 0 0}$ & $\mathbf{2 0 1}$ & $\mathbf{2 0 1}$ & $\mathbf{2 0 1}$ & $\mathbf{2 0 1}$ & $\mathbf{2 0 1}$ & $\begin{array}{c}\text { Jumla } \\
\mathbf{h}\end{array}$ \\
& $\mathbf{4}$ & $\mathbf{5}$ & $\mathbf{6}$ & $\mathbf{7}$ & $\mathbf{8}$ & $\mathbf{9}$ & $\mathbf{0}$ & $\mathbf{1}$ & $\mathbf{2}$ & $\mathbf{3}$ & $\mathbf{4}$ & $\mathbf{h}$ \\
\hline employee & & & & & & & & & & & & \\
Other & 0 & 6 & 1 & 2 & 4 & 4 & 9 & 3 & 3 & 8 & 8 & 48 \\
\hline $\boldsymbol{\Sigma}$ & $\mathbf{4}$ & $\mathbf{2 3}$ & $\mathbf{2 9}$ & $\mathbf{2 7}$ & $\mathbf{5 5}$ & $\mathbf{4 5}$ & $\mathbf{6 5}$ & $\mathbf{3 9}$ & $\mathbf{5 0}$ & $\mathbf{5 9}$ & $\mathbf{4 8}$ & $\mathbf{4 4 2}$ \\
\hline
\end{tabular}

As we could see, it is really sad and also embarrassing to see how many government employees and those who became member of house of representative involved in corruption activity. They have shows us the worst morale, and make us think " is this Indonesia?"

Pergaulan bebas of translated as Promiscuity defined as deviation behavior, "bebas" or "free" in this context mean exceed the eastern norms. It is now happen in Indonesia and we could found it in any societies, and mass media. In Indonesia, we don't have regulation related to abortion legalization, because it is consider contradicted with Pancasila values, religion and other positive law. Many opinion said that abortion legalization will trigger more promiscuity in the societies. National statistic data related to HIV/AIDS patient in Indonesia shows that in 2012 about $75 \%$ of it is teenagers.

From the Survey of Indonesia Health Demographic show that teenager reach $30 \%$ of total population or about 12 mill. Nowadays, there are so many early marriages that involved teenager, pre marital sex activities, unwanted pregnancy, abortion cases. While from the National Narcotics Bureau, drug violation involving teenager show increase in number. From $2.21 \%$ (4 mill ) in 2010 to $2.8 \%$ (5 mill) in 2011.

Not prevented drugs violation, abortion, pornography and vandalism has been "social disease" that threatened societies as an entity. It has been a threat for economic and moral of a nation in the future.

From the Child Commission data, juvenile delinquency cases has been increased in the last six months of 2012. Until June there were 139 inter school fights cases, and the 12 of it had caused deaths. In 2011, there were 339 cases with 82 child murdered.

The increase of juvenile delinquency that happened every year is not solely caused by one behaviour deviation; it is caused by various violations form of religion, society norms or school regulations. And every incident will have significant impact to the teenagers themselves. If they are not join rehabilitation program, it will be possible that they will grow into bad behavior citizen and always have a tendency to harm other. (http://kenakalanremaja.blogspot.com, tangal 9 januari 2013 jam 13.30).

Above is an objective fact according to the writer, and it has show that Indonesian almost lost their identity. Indeed, it is severe problem that faced by us, the Indonesian, nowadays. Many incidents happened in last years already categorized as a threat for the nation; social conflict and violent terror had destroyed our social capital. Corruption, collusion and nepotism had made us as a nation with low trust society

Technology improvement and information globalization certainly have positive impact for our daily life. Only with one personal computer and an internet connection, everyone will be able to access various information around the world with very afordable price. Although in other side, we must admit that it also contain negative impact particularly for the youngsters. 
Adult content within the internet become more familiar for the teen, and sadly including the pre teen. Such content even easy to found around us; tabloid and adult paper even add hot line to contact. I guess sooner or later it will affect the Indonesian culture, particularly the youngsters, whom still searching their identity. As the result, slow but sure, we can felt that Indonesian have lost the sense of "shame".

Based on the description above, we need to take afirmative action to revitalize Indonesian Identity; particularly through character education. Thus we can bring back the Indonesian Identity.

This is the time for High Education to sthrenthen national identity as one of a huge nation with various ethnicities and religions. It also must be able to shape the community to be more discipline, civilized and ethic.

Thus the conclusion is character education is a significant thing to revitalize Indonesian identity, particularly when it held in High Education level. It is expected could result a qualified students. Since only strong character nation will able to be succeed internationally.

\section{Character Education}

There are 18 points of character education (1) religious, (2) Honest, (3) Tolerance, (4) Discipline, (5) Hard work, (6) Creative), (7) Independent, (8) Democratic, (9) curiousity, (10) Spirit of nationalism, (11) patriotism, (12) appreciating every achievement, (13) friendly/ communicative, (14) Peace lover, (15) love to read, (16) caring the environment, (17) Caring the society, and (18) responsible.

All those eighteen points described as follow :

1. Religious : consistantly implementing his/her faith and tollerance to other faiths and its believers.

2. Honest : is an effort of a person to make him/her self could be trusted for every words and action.

3. Tolerance : is and attitude and action to respect every differences exist in the society, including faith, opinion, attitude, and action.

4. Discipline: an action that shows obeyness to every regulation and rule.

5. Hardwork : Behavior that show a trully effort to cope every obestacles

6. Creative : Thinking and doing something to result a brand new way from the regular known habit.

7. Independent : An attitude and behavior that not easy to be dependent to other

8. Democratic : Way of think, attitude and action that support the equity of his/her responsibilities and rights with others.

9. Curiousity : An attitude and action that shows an effort to gain more knowledge of something he/her learned.

10. Spirit of nationalism : way of think, act, and ideas to place the nation first before him/her

11. Patriotism : Way of think, behavior, and action that show the loyalty, caring and respect to the language, physical environment, social, culture, economic and national politics.

12. Appreciating every achievement : an atiitude and action that motivate him/her self to result something useful for the society; and admiting any other person succees

13. Friendly/ Communicative : an action that show the interest to communicate, socializing, and ccoperative with other. 
14. Peace lover : An attitude, words and action that cause other feels happy and save to have him/her.

15. Love to read: A habit to spend the time to have qualified reading

16. Caring the environment : An attitude and action that show an effort to prevent natural damage, and then develop efforts to revitalize the damage.

17. Caring the society: An attitude and action that show an effort to help other

18. Responsibility : an attitude and effort to implementing his job and responsibility for self, other and Thee God.

For Indonesian, today, character education also mean to do a sistematic and sustainable effort to rise and strengthen all Indonesian awareness to re-strength the character. As Theodore Roosevelt stated "“To educate a person in mind and not in morals is to educate a menace to society".

Character education has been a focus of various countries to prepare the qualified next generation. . character education can be describe as the deliberate us of all dimensions of school life to foster optimal character development.

Character education is based on human basic character that sourced from universal absolute value, such as religion or we called it the golden rule. The aim of character education is similar to moral eductaion, which is to shape a person to be a good individual, good society member and a good citizen of the country. Thus, the essence of character education is value education; which is the education of high values sourced from the religion and culture.

The conclusion is character education has higher level than moral education. It is not only teach about which right and wrong; but also to make the students understand which right and wrong, and able to feel it and then direct them to be willing to implement it on a daily basis.

\section{Indonesian Identity}

Pancasila is the Indonesian identity that makes them different from other nation. National identity is a choice that reflect the character of a nation. It is an accumulation or synergy of individual character. It is derived from the highest values of the real life and than formulate it to be a one value system.

Pancasila known as Indonesian guidance and ideology. We may found many values that build national culture and character. Thus if the government and the citizens willing to bring back the national identity into their daily life, they must be able to understand the meaning of every pillars contains in Pancasila. If we relate it with recent conditions, Pancasila is a formula of ideal values that conceptualy able to give politics guidance for the government and citizens about how to resolve national problem with independent way and dignity. As an ideology, it has prime character as national ideology. It is a reflection of whole Indonesian way of think and method to gain the objectives; to build a prosper country. It is also act as a tool to unite the citizens and build strong relation between the citizens and the country.

Pancasila and identity is two side of a coin. It is an ideal and philosophy ground for the nation; a source of the law in Indonesia. While identity is a daily implementation of it; as describe below : 
1. Believe in the one and only God

It is an establishment of religious Indonesian. As nation whom the citizens have a faith in God, it is clear that Indonesia is not a pure secular country. With Moslem majority citizens, Indonesia is an ideal example to present positive tolerance among the six official religions; a citizens status is not determined by their religion. This situation is hard to found in mostly Muslim majority countries. Here we could make a conclusion that the identity of Indonesian is a religious society that applies religiosity concept.

2. Just and Civilized humanity

ishment of Indonesian second identity is respecting the Human Rights. Indonesia is a country that based on a law. Within the country based on law, the authority of government/country implemented based on justice principle. Thus, they are strongly attached to the rule of law. The principle used by a law based country is there is power sharing among the government institutions and they must provide the guarantee for human right implementation for the citizens.

As a national principle, there are no values contain in Pancasila that contrary with the Human right values. If we deep analyze this second pillar, in a philosophy term it is related with the basic formula of politics ethic. The Indonesian expected to have the just and civilized attitude, so they could be able to implement the justice, tolerant and respecting other people's right. The core of this pillar is humanity concept.

3. Unity of Indonesia

This pillar is a reflection of the Indonesian whom has high nationalism; the nationalism here refer to the sense of pride, sense of belonging, appreciating, respecting and loyalty to the country. This pillar states about nationalism concept.

4. Democracy led by the wisdom of deliberations among representatives

Indonesian is a democratic citizens. Generally, we can say that democracy is a political system that possibly every citizen to have an equal chance to express their aspiration. Democracy implemented in Indonesia is different with any other countries, because we use Pancasila as the basic foundation of it. Democracy in Indonesia is not only about politics, but also in economics and social. Or, we can say that democracy in Indonesia is the democracy of welfare and happiness. Within this pillars we could see the concept of sovereignty.

5. Social Justice for All Indonesian People

The fifth pillar basically is about togetherness of Indonesian. Social justice considered as a bridge to gain people welfare.

The five pillars of Pancasila are philosophical fundament and also an ideology to achieve national goals, as mentioned in the Preface of UUD 1945 (Indonesian Constitution), which are :

1. Protecting every Indonesian citizens and land.

2. Improving the social welfare

3. To educate all Indonesian citizens

4. Participating to keep the world peace, based on independency principle, absolute peace and social justice.

Pancasila as the Indonesian identity is also functioned as a mark that differ the Indonesian and other. National identity is a thing that important to have by every nation in the world, to possibly every nation run their own country using their special unique characters.

If a country do not have its own identity, it will imitate it from other nation; while in the other side, the imitated identity might not be suit for them. As the result, that nation might be weak internally and could easily dominated by other nation. 
From the above description, we can realize about the importance of national identity. In the context of this writing, I see that the Indonesian character is slowly fade; and it caused its identity became weak. This condition makes us need to take effective steps to revitalize it.

\section{Revitalization Of Indonesian Identity To Improve The Quality Of High Education In Indonesia}

Why do we need to revitalize the national identity? What is actually missing of this country, why people suddenly become uncivilized. Moral decadence seems to be happen everywhere at any levels.

Cultural institution no longer respected. The role of traditional institution to guide the society already disappeared. Indonesia has infected by demoralizing. Sadly, the condition is worsening by the government attitude whom no longer take a serious effort to rise nationalism spirit. Since the spirit of reform raised to replaced the old order of Soeharto, Indonesa also slowly lose its character. Recently, Indonesian suffers chronic social pathology. Most youngster had choose non conservative-traditional way of life, as a reason to support transparency and democratic atmosphere.

National character is a quality of collective attitude that reflecting in people awareness, understanding, sense and behavior. In this case, Indonesian character that determine the collective behavior, must be based to the Pancasila Values, Indonesian Constitution 1945, Bhineka Tunggal Ika principle, and commitment to the country. This character will shows the Indonesian identity.

To obtain the expected nation's characters, Indonesia will need individual with characters. Thus, we need hard effort to build citizens to have such an ideal characters. Psychologically, individual character is a set of four elements, which are ; intuition, analyzing, physical/ kinetic, senses and intention. Intuition is strongly related to feeling and faith. Analyzing related to the process of reasoning to search and use the knowledge in a critical, creative and innovative way. Physical related to perception process, readiness, imitating, manipulating and the creation of new activity that contain sportsmanship. Senses and intuition related to willing and creativeness that appear in caring, imaging and the creation of something innovative.

Individual character that have implementing Pancasila pillars are :

1. Character that based on intuition are have faith in God and implement it, honest, just, following the rule, responsible, empathize, dare to take the risk, willing to sacrifice and patriotic.

2. Character that based on analyzing are smart, critic, creative, innovative, curious, productive, technology oriented and reflective.

3. Character that based on physic/kinetic are clean and health, have sportsmanship spirit, reliable, immune, friendly, cooperative, determinative, competitive, nice and persistence.

4. Character that sourced from senses and intention is humanity, respect each other, togetherness, respect each other, tolerant, nationalist, caring, cosmopolite, make first of public need, patriotic, proud to use language and Indonesian product, dynamic, hard worker, and have work ethic.

The fourth elements are related to one another and it will make a sense if some of character aspect is a result of several processes. National identity could be shaped through the example shows by the country's leader, whom have the spirit to make a change globally and 
transformational, but also still have strong nationalism. He/she don't have to be a statesman to be it.

Leadership characters (Muladi:2006) that could be a good example are:

1. Change leadership that could do a positive synergy between enthusiasm, energy and hope. $\mathrm{He} / \mathrm{she}$ also must have moral purpose, understanding the change, coherence making, relationship building, knowledge creation and sharing. Within the culture of change, a leader will experience or enjoying the challenge to solve the obstacles. And the biggest success is happen when effective leaders make people feel that even the most difficult problems can be tackled productively.

2. Transformational leadership characters are:

a. Able to set out bold vision;

b. Skilled in marshalling the intellectual and emotional equity of their people;

c. Caring for the individual at the highest level;

d. Ability to mind the mind;

e. Quick to recognize good ideas and have the intellectual honesty;

f. The imperative on institutionalization, to ensure continuity without disruption;

g. Willingness to move away from his conventional role;

3. In global leadership, the concept is based on a complex social trust and global sense. There are five characteristics related to it :

a. Thinking globally, where the leader must understand various differences of economic system, culture, law and politics; as a part of world citizen. He also must have open ended vision and values. Global leaders need to have a global level when making decisions (think globally act locally).

b. Appreciating cultural diversity. In this case, diversity of leadership style, industry style, individual behaviors and values, race, religion and sex, as a key to competing successfully in the future.

c. Developing technological savvy, which without it will be impossible to create cooperation and global networking.

d. Building partnership and alliances. In the future, we will need collaborative leader that could organize teams with various skills.

e. Sharing leadership is a leader with effective decision within an integrative work condition.

Since Indonesian follow paternalistic culture, there always huge possibility that the people will follow whatever the leader do. That is why the leader must start to give their best example to the people.

National identity could be revitalized through character education. Because character education is an intentionally and planned effort to establish the empowerment and internalization positive potency of the students, thus they could have a good-unique character as a citizens. Character education is expected could give a best contribution to create a Pancasila based society. It is also intended to solve the social pathology problem.

As mentioned before, character education is an education that based on honestly, sincerity, responsibility and trust. Otherwise, this kind of education can be succeed if the community needs it; if they don't need it, all of it will be useless. The implementation of character education in macro context is a commitment of all life sectors within the country, not only a matter of national education sector. In the micro context this kind of education is established by a family unit. A family has a role to serve a foundation to internalizing the character through their members. 
Government must be able to be the perfect example for nation character internalization. Good government is a reflection of a good community. Characterized community is refection of characterized citizens. Therefore, government must always stand in the first row as an ideal example.

\section{CONCLUSION AND RECOMMENDATION Conclusion}

Indonesian is a religious nation, thus the values within their religion will be a foundation to build nation character. Pancasila is placed as a higher source of the law because it is a national foundation. Since Indonesia is built from various ethnics and culture; then national characters must be based on the local culture. Within the context of higher education, with religions, pancasila and culture as a sources, the national characters established in the national education goal. Values developed within the national character education identified from the core sources (religion, Pancasila, and national education goal).

In Regulation No.20, 2003 about National education system stated that national education functioned to develop the skill and shaping the character and civilized the community. Thus, sociologically, education must be able to help Indonesian to have ability to understand the humanity symbols.

Identity is a characteristic of a nation that distinguished them from any other nations. It is a choice and a reflection of Indonesian character. National character is an accumulation or synergy of individual character. It will be appeared as highest level values and the formulated it into a value system known as Pancasila. Until now, Pancasila is a fundament and ideology of the nation that contains values, which built character and national culture.

\section{Recommendation}

If high education institution willing to improve its quality, they must be able to bring back the national identity. They must internalize the value of pancasila to the student. Pancasila is a national foundation that being a reflection of the ideal values, which conceptually could be political guidance for the people and the government. Particularly, related to how to solve the national problem independently and with dignity. In other side, pancasila also could unify the nation and build strong relation between the country and its citizens, thus the revitalization of national identity expected could improve the quality of High education in Indonesia.

\section{REFERENCES}

Efendi, Taufiq, 2008. Indonesian Identity Towards Great Nation. Jakarta, Exatama Mediasindo

Elmubarok, Z., 2009. Socializing Value Education: Collecting the spreads, thightening the loss and unifying the entities, Bandung: Alfabeta,

Endang, Sumantri, 2010. Character Education the Hope for Future National Education. UPI

Dali Gulo dan Kartini Kartono. 1987. Physicology Dictionary. Bandung, Pionir Jaya

Kertajaya Hermawan, 2010. Differentiation. Jakarta, Gramedia

Lickona Thomas. 2004. Educating For Character: How Our Schools Can Teach Respect And Responsibility (in Nuraini Farida, 2014. Sunan Kalijaga Yogyakarta)

Muladi. 2006. Panel discussion : "National Identity Revitalization" established by Bereau Of Organization And Public Relation, State Secretariate Deputy Chamber Of Human 
Resources, And Bereau Of Authority And Knowledge, Vice President Secretariate Deputy Chamber Of Politics On June 14th, 2006 At Republic Of Indonesia State Secretariate Office, Jakarta

Mulyadi, Seto dkk, 2008. Character Building:How To Educate Child With Character, printed I, Yogyakarta: Tiara Wacana.

Musthafa, Fuham, Asy-syaikh, 2004. Guidance for Moslem Child Education, First Print, Jakarta: MUSTAQIM,

Shulhan, Najib. 2010. Character Based Education, First Print, Surabaya: Jaring Pena

Suyanto Slamet. 2009. Character Education Through Sistematic Learning. Yogyakarta

Suhartono, Suparlan, 2006. Philosophy of Education, First Print, Jogjakarta: Ar-Ruzz.

Sofan, Moh. Education with Profetic Paradigm: Constructive Effort to Analize the Dicotomy in Islamic Education System. Yogyakarta: Ircisod, 2004.

Regulation No 20, 2003 about National Education System.

https://stf1100025.wordpress.com/2011/07/30/pendidikan-berbasis-karakter/

http://kenakalan-remaja.blogspot.com 